\title{
Erratum zu: Emerging COVID-19 reinfection four months after primary SARS-CoV-2 infection
}

\author{
Redaktion „Wiener Medizinische Wochenschrift“
}

Online publiziert: 18. März 2021

(C) Springer-Verlag GmbH Austria, ein Teil von Springer Nature 2021

\section{Erratum to:}

Wien Med Wochenschr 2021

https://doi.org/10.1007/s10354-021-00813-1

The original version of this article, unfortunately contained a mistake. ship.

The article was published with incomplete author-

The correct authorship is:

Helmut J. F. Salzer ${ }^{1}$, Matthias Neuböck ${ }^{1}$, Sven Heldt $^{1}$, Isabella Haug ${ }^{1}$, Christian Paar ${ }^{2}$, Bernd Lamprecht $^{1}$

${ }^{1}$ Department of Pulmonology, Kepler University Hospital, Linz, Austria

${ }^{2}$ Institute of Laboratory Medicine, Kepler University Hospital, Linz, Austria

We ask that you note the correction and apologize for the mistake.

The Editorial Office

\section{Erratum zu:}

Wien Med Wochenschr 2021

https://doi.org/10.1007/s10354-021-00813-1

In der Originalpublikation des Beitrags kam es leider zu einem Fehler.

Der Beitrag wurde mit einer unvollständigen Autorenschaft publiziert.

Die korrekte Autorenschaft lautet:

Helmut J. F. Salzer ${ }^{1}$, Matthias Neuböck ${ }^{1}$, Sven Heldt $^{1}$, Isabella Haug ${ }^{1}$, Christian Paar $^{2}$, Bernd Lamprecht $^{1}$

${ }^{1}$ Department of Pulmonology, Kepler University Hospital, Linz, Austria

${ }^{2}$ Institute of Laboratory Medicine, Kepler University Hospital, Linz, Austria

Wir bitten, die Korrektur zu beachten und den Fehler zu entschuldigen.

Die Redaktion 